\title{
Asymmetric Alkene Epoxidations Catalyzed by Sterically Hindered Salen-Mn(III) Complexes
}

\author{
Yong-Chul Jeong, Sunho Choi, Kyunga Yu, and Kwang-Hyun Ahn* \\ College of Enviromment and Applied Chemistry, and Institute of Natural Science, \\ Kyung Hee University, Yongin City 49-701, Korea \\ Received Jamary 13, 2003
}

Key Words : Asymmetric, Epoxidation, Salen, Enantioscleclivily

In recent years, many approaches have been developed for the preparation of enantiomerically pure epoxides.' Among these are olefin epoxidations catalyzed by chiral salen$\mathrm{Mn}$ (III) complexes such as 1-3, which now rank among the most efficient of methods uncovered for the synthesis of chiral epoxides. ${ }^{2}$

It is known that bulky substituents, including t-butyl and aryl groups, at the $\mathrm{C} 3$ and $\mathrm{C} 3$ ' positions of the ligands are required to obtain high degrees of enantioselectivity in chiral salen-Mn(l]1) catalyzed epoxidations of alkenes." We have observed similar results in an earlier study with sterically hindered salen ligands. ${ }^{+}$However, salen ligands containing alkyl substituents larger than $t$-butyl at the $\mathrm{C} 3$ and $\mathrm{C} 3$ positions have not been subjected to detailed investigation thus far. ${ }^{5}$ Consequently, we have prepared a series of sterically hindered chiral salen-Mn(ll]) complexes, such as $\mathbf{4}$, and have probed their use in enantioselective epoxidation reactions of alkenes.

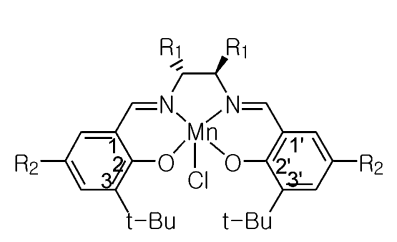

(R)-1 $\mathrm{R}_{1}=\mathrm{Ph} \mathrm{R}_{2}=\mathrm{t}-\mathrm{B} \mathrm{L}$ (R) $-2 \mathrm{R}_{1}=\mathrm{Ph} \mathrm{R}_{2}=\mathrm{OCH}_{3}$ (R) $-3 \mathrm{R}_{1}=\mathrm{Ph} \mathrm{R}_{2}=\mathrm{OSi}(\mathrm{i}-\mathrm{Pr})_{3}$

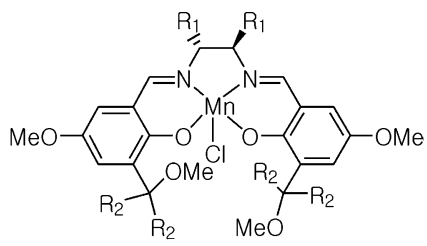

(R) $-4 \mathrm{R}_{1}=\mathrm{Ph} . \mathrm{R}_{2}=\mathrm{Et}$ (R) $-5 \mathrm{R}_{1}=\mathrm{Ph}, \mathrm{R}_{2}=\mathrm{n}$-propyl

(R) $-6 \mathrm{R}_{1}=-\left(\mathrm{CH}_{2}\right) 4-\mathrm{R}_{2}=$ neopentyl

(R) $-7 \mathrm{R}_{1}=\mathrm{Ph}, \mathrm{R}_{2}=$ neopentyl

(R) $-8 \mathrm{R}_{1}=\mathrm{Ph}, \mathrm{R}_{2}=\mathrm{Ph}$
The aldehyde 12, which served as the key intermediate in the synthesis salen complexes $\mathbf{4}$, was prepared starting with readily available 4 -methoxysalicylic acid (Scheme 1). The sequence involved esterification, double alkylation and formylation." Each step in the route, except for the formylation process, proceeded in greater than $90 \%$ yield. Reaction of the aldehyde $\mathbf{1 2}$ with chiral diphenylethylenediamine gave the salen ligand, which was metallated with $\mathrm{Mn}(\mathrm{OAc})_{2}$ and $\mathrm{LiCl}$ to yield the salen-Mn(III) complex $4^{3.7}$

The catalytic activity of 4 for epoxidation of alkenes was determined by using Jacobsen's conditions and $\mathrm{NaOCl}$ as the oxidant." 'The results, summarized in Table 1, show that 4 efficiently catalyzed the epoxidation of styrene (entry 2). However, the enantioselectivity of this process (68\%ee) is only slightly higher than that obtained by using the Jacobsen's catalyst (entry 1). To evaluate the steric effects of the salen $\mathrm{C} 3$ and $\mathrm{C} 3$ ' substituents on the enantioselectivity of the reaction, complexes 5-8 were also prepared by using the general methodology shown Scheme l and employing different Grignard reagents. Although active, the catalyst $\mathbf{5}$ with bis-n-propyl substituents at $\mathrm{C} 3$ and $\mathrm{C} 3$ gave low levels of enantioselectivity (entry 3). Catalysts 6-8, containing more bulky substitution at these positions, also showed low levels of enantioselectivity as well as low reaction yields (entries 4-6). These results suggest that the $\mathrm{C} 3$ and $\mathrm{C} 3^{\prime}$ substituents of salen ligand need to be properly tuned in order to obtain the high enantioselectivities.

Interestingly, excellent levels of catalytic activity and enantioselectivity are observed in epoxidation reactions of sterically hindered olefins, catalyzed by salen complex 4 . For example, epoxidation of cis- $\beta$-methylstyrene catalyzed by 4 proceeded with a $98 \%$ ee and a cis/trans epoxide ratio of 28 (entry 8 ) that is higher than that obtained in any other $\mathrm{NaOCl}$ promoted reaction of this olefin at $0^{\circ} \mathrm{C}$. In contrast, Jacobsen's catalysts 1 and 2 gave respective enantioselectivities of only $85 \%$ ee and $83 \%$ ee with cis- $\beta$-methylstyrene. Salen complex 4 also displayed an excellent catalytic activity (up to $99 \%$ ee) in epoxidation reactions of other alkenes, including indene. 1,2-dihydronaphthalene and 2,2-dimethylchromene (entries 13-22).

LiOCI has been employed frequently in place of $\mathrm{NaOCl}$ in Mn(III)-porphyrin catalyzed epoxidations of olefins. ${ }^{9}$ As a result. the use of the lithium containing oxidant in epoxid-<smiles>COc1ccc(O)c(C(=O)O)c1</smiles>

9

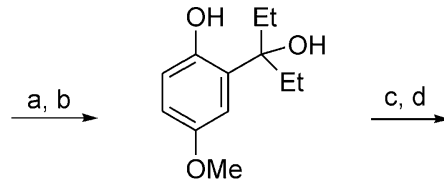

10<smiles>CCC(CC)(OC)c1cc(OC)ccc1OC</smiles>

11

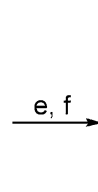<smiles>CCC(C)(C)c1cc(OC)cc(C=O)c1O</smiles>

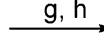

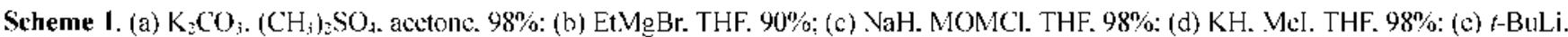

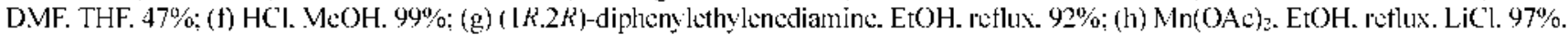


Table 1. Salen-Mni( IIT)-Complex Catalyzed NaOCl Fpoxidations of Olefins

\begin{tabular}{|c|c|c|c|c|c|c|}
\hline Jimlsy & Alkene & C'alulyst & $\begin{array}{l}\text { Time } \\
\text { (hr) }\end{array}$ & Yield ${ }^{\alpha}$ & $\because 0 \mathrm{ee}^{b}$ & Config. \\
\hline 1 & Sţrene & $(R)-1$ & 4 & 53 & 6.5 & $(R)^{5}$ \\
\hline 2 & & $\left(S^{\prime}\right)-4$ & 2 & 97 & 68 & $(S)$ \\
\hline 3 & & $(R)-5$ & 4 & 88 & 61 & $(R)$ \\
\hline 4 & & $(R)-6$ & 8 & 26 & 33 & $(R)$ \\
\hline 5 & & $(R)-7$ & 8 & 28 & 42 & $(R)$ \\
\hline 6 & & $(S)-8$ & 8 & 11 & 29 & $(S)$ \\
\hline 7 & $(i s$ - $\beta$-m]ethyslysene & $\left(S^{\prime}\right)-1$ & 4 & 90 & $85(17)^{d t}$ & $(S, R)^{6}$ \\
\hline 8 & & $(S)-4$ & 2 & 91 & $98(28)^{d 7}$ & $(S, R)$ \\
\hline 9 & & $(R)-5$ & 2 & 58 & $90(7.0)^{d t}$ & $\left(R, S^{\prime}\right)$ \\
\hline 10 & & $(R)-6$ & 4 & 34 & $93(2.1)^{d t}$ & $\left(R, S^{\prime}\right)$ \\
\hline 11 & & $(R)-7$ & 4 & 22 & $75(9.6)^{d t}$ & $(R S)$ \\
\hline 12 & ludene & $(R)-1$ & 8 & 801 & 84 & $(R S)^{5}$ \\
\hline 1.3 & & $(S)-4$ & 4 & $6.3(95)^{e}$ & e $84(9)(1)^{e}$ & $(S . R)$ \\
\hline 14 & & $(R)-6$ & 4 & 69 & 84 & $(R S)$ \\
\hline 15 & & $(R)-7$ & 4 & 51 & 89 & $(R . S)$ \\
\hline 16 & 1.2-1 bibydromaphithaleje & $(R)-1$ & 8 & 62 & 77 & $(R S)^{3}$ \\
\hline 17 & & $(S)-4$ & 3 & $64(80)^{e}$ & $601(95)^{e}$ & $(S R)$ \\
\hline 18 & & $(R)-5$ & 4 & 38 & 95 & $(R S)$ \\
\hline 19 & & $(R)-6$ & 4 & 52 & 94 & $(R S)$ \\
\hline 20 & & $(R)-7$ & 4 & 64 & 76 & $(R S)$ \\
\hline 21 & 3-Chlorostyene & $(S)-4$ & 8 & 71 & 5.3 & $(S)$ \\
\hline 22 & 2.2-I)imethỵlchromene & $(S)-t$ & 8 & 73 & 99 & $(R S)$ \\
\hline
\end{tabular}

"GC vields (entries 1-11) or isolated vields (entries 12-22). "Delemined by GC with either Supeleo chiral $\beta$-dex $325(30 \mathrm{~m} \times 0.25 \mathrm{~mm} \times 0.25$ Hum, entries 1-11, 16-20) column and IIPI.C with either Daicel Chiralecl Of column (entries 12-15) or OD column (entries 21-22). "Absolute conliguration was assigned according to the literature procedure. "The cis trons ratio. "T.iOCl was used instead of $\mathrm{NaOCl}$.

ation reactions catalyzed by the salen complex 4 was investigated. Interestingly epoxidations of indene and 1.2dilyydronaphthalene were found to occur in high yields (entries 13 and 17) and with slightly higher degrees of enantioselectivity than when $\mathrm{NaOCl}$ is used as the oxidant.

To determine the relative reactivities of the two oxidants. $\mathrm{LiOCl}$ and $\mathrm{NaOCl}$. reactions of styrene catalyzed by salen complex 4 were studied. As shown in Figure 1. the overall yields of the reactions with both $\mathrm{LiOCl}$ and $\mathrm{NaOCl}$ after $3 \mathrm{~h}$ were ca. $45 \%$, which were lower than that obtained (97\%) by using $+\mathrm{mol} \%$ of catalyst 4 (entry 2 ). This observation indicates that the catalyst becomes inactive after $c a .+5$ turnovers. However. the enantioselectivities obtained with both $\mathrm{LiOCl}$ and $\mathrm{NaOCl}$ were the same as that obtained when $+\mathrm{mol} \%$ of the catalyst and $\mathrm{NaOCl}$ were used. This result indicates that the level of enantioselectivity is not dependent upon either the amount of catalyst or the type of hy pochlorite used. Especially noteworthy is the observation that the rate of the epoxidation reaction using $\mathrm{LiOCl}$. was twice that of the process promoted by $\mathrm{NaOCl}$. The higher rate observed with LiOCl may be due to faster oxygen atom transfer from aqueous $\mathrm{LiOCl}$ to the salen-Mn(III) catalyst.

In summary. we have synthesized new chiral salen-Mn(III) complexes $4-8$ and shown that they serve as an efficient cataly st for $\mathrm{NaOCl}$-induced epoxidations of olefins. Finally, we have shown that $\mathrm{LiOCl}$ could be employed as an oxidant

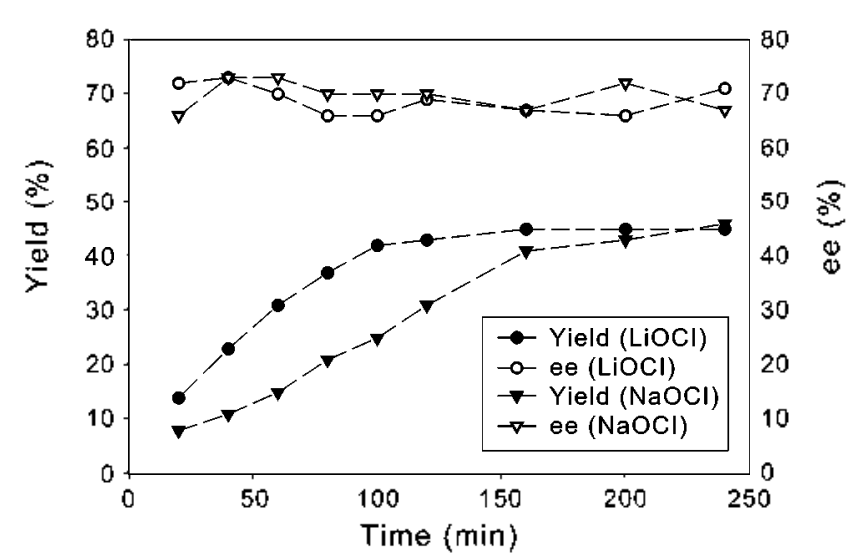

Figure 1, lime course of the yicks and enentioselectivities of epoxidation reactions of styrene catalyzed by 4 in the presence of either $\mathrm{NaOCl}$ or $\mathrm{I}, \mathrm{iOCl}$.

in these epoxidation reactions and that the reaction rates with the lithium containing oxidant were higher than those promoted by $\mathrm{NaOCl}$.

Acknowledgement. This work was supported by a grant from Korca Rescarch Foundation (2001-005-D00004).

\section{References and Notes}

1. Sheldon, R. A. Chirotechologn: Marcel Detiker: New York. 199.3: Chapter 9.

2. (a) Katsuki, T. In Comprehensive Asummetric Cotahsis, fol $\mathrm{H}$ : Jacobsen. E. N.: l'aultz. A.: Yamamoto. H.. Eds.: Springer-Verlag: Berlin. 1999: p 621. (b) Jacobsen. E. N.: Wu. M. H. In (omprehensive Assmmetric (atdhsis, fol hl. Jacobsen. E. N.: P'lullz. A.: Yamamoto, II., F.ds: Springer-Verlag: Berlin. 1999: p 649. (c) Aggarwal. V. K. In Comprehensive Astmmetric Catalysis, follt: Jacobsen, Г.. N.: Ptaltz, $\Lambda$.: Yamamoto, H., F.ds.: Springer-Verlag: Berlin. 1999: p 679.

3. (a) Zhang. W.: Loebach. J. L.: Wilson. S. R.: Jacobsen. E. N. $J$. in. Chem Soc 1990. //2. 280l. (b) Irie. R.: Noda. K.: Ito. Y.: Matsumoto, N.: Katsuki, T. Terrohedron Letl 1990. 31, 7.345.

4. (a) Katsuki. T. Coond Chem. Rev 1995, 140, 189. (b) Ito, Y. N.: Katsuli, T. Bull. Chem. Soc. Jpn. 1999. 72, 603.

5. Ahr. K.-H.: P'ark. S. W.: Choi. S.: Kim. H.-J: Moon. C. I. Tetrahedron lett. 2001. +2. 2485 .

6. (a) Hosoya. N.: Hatayama. A.: Yanai. K.: Fujii. H.: Irie. R.: Katsuki, T. Sylkt 1993. 64l. (b) Gacuere, A.: I iang. S.: H Isu. F.I..: Bu, X. R. Tethohedron: Astmmetry 2002, 13. 2089

7. Analytical data for 12: 'II-NMR (CDCl $3.400 \mathrm{MIJ}) \delta 10.59$ (s. IH). $10.13(\mathrm{~s} .1 \mathrm{H}) .7 .25(\mathrm{~d} . J-3.16 \mathrm{~Hz} .1 \mathrm{H}) .7 .02(\mathrm{~d} . J-3.16$ $\mathrm{Hz}) .3 .81(\mathrm{s.} 3 \mathrm{H}) .3 .24(\mathrm{s.} 3 \mathrm{H}) .2 .08(\mathrm{~m} .2 \mathrm{H}) .1 .93(\mathrm{~m} .2 \mathrm{H}) .0 .68(\mathrm{t}$. $J-7.56 \mathrm{~Hz}):{ }^{1.7} \mathrm{C}-\mathrm{NMR}\left(\mathrm{CDCl}_{3}\right) \delta 193.83 .154 .26 .152 .13$. $1.31 .99,124.97,121.46 .111 .07,8.3 .37 .55 .76 .+8.68 .26 .07 .7 .66 \%$ IIRMS $(\mathrm{F} \wedge \mathrm{B}) m z$ calcd $\mathrm{C}_{11} \mathrm{H}_{18} \mathrm{O}_{1}(\mathrm{M}+2 \mathrm{H})^{\prime} 252.1362$. found 252.1368

8. Analytical data for 4: $\mathrm{C}_{42} \mathrm{H}_{50} \mathrm{O}_{6} \mathrm{~N}_{2} \mathrm{MnCl} \cdot 1: 2 \mathrm{H}_{2} \mathrm{O}$. C. 64.82: $\mathrm{H}$. 6.61: N. 3.61. found C. 64.59: H. 7.14: N. 3.21. mp 210-212 "C.

9. The typical procedure used for the epoxidation reactions is as follows: To a stirred solution of 1,2-dihydromaphthalene (0.5 mmol), in $\mathrm{CH}_{2} \mathrm{Cl}_{2}(2.5 \mathrm{ml})$, catalyst $(0.02 \mathrm{mmol})$ and 4phenylpridine-1-oxide (4-PPNO, $0.1 \mathrm{mmol}$ ) at $0^{\circ} \mathrm{C}$ was added pre-cooled buflered bleach $(2.5 \mathrm{mmol}$. bullered to $\mathrm{pH} 11.3$ with $\mathrm{Na}-\mathrm{HPO}_{4}$ ). The mixture was stirred for $3 \mathrm{~h}$. The organic phase was separated. dried $\left(\mathrm{MeSO}_{1}\right)$ and concentrated in racuo giving a residue which was subjected to silica gel chromatography:

10. Collman, J. P. Brauman, J. I.: I Jamptom, P.; Tanaka, I .; Bohle, D. S.: Jembre, R. T. $J$. th Chem. Soc. 1990, 112,7980. 